Vladimir Ristić ${ }^{1}$

Olga Mirković Isaeva ${ }^{2}$

Bojana Vasić ${ }^{3 *}$
JEL: F52

DOI: 10.5937/industrija46-17194

UDC: 005.52:330.15

330.34

Original Scientific Paper

\title{
Management of natural wealth - resources curse and socio-economic development
}

\author{
Article history: \\ Received: 17 March 2018 \\ Sent for revision: 18 April 2018 \\ Received in revised form: 6 May 2018 \\ Accepted: 14 May 2018 \\ Available online: 29 June 2018
}

\begin{abstract}
The phenomenon of the resource curse is based on the assumption that countries with large natural resources are unable to achieve adequate economic development, and cannot provide benefits to their citizens. High impact on this issue lays in inadequate management of human resources and corruption. The main objective of this paper is to examine the basic assumptions of the theory of resource curse, to determine the factors that have the greatest impact on its (non)existence, to determine the causal dependence between natural wealth and the political environment, as well as with the quality of life of citizens. The research was carried out by analysing five variables that define resources curse and Human Development Index. For data processing, Fisher's $F$ test is applied. The survey was done on a sample of 22 countries. The results show: a) the characteristics of the political regime do not have a clearly defined impact on existence of resource curse, b) resources rent and export of energy products do not have a significant impact on the quality of life of citizens (expressed through the Human Development Index) and c) a significant degree of deviation from the expected is determined in countries rich in ores and metals.
\end{abstract}

Keywords: natural wealth; management; economic development; social wellbeing

\footnotetext{
${ }^{1}$ University of Defence in Belgrade, Serbia

2 Technologies without limits LLC, Russian Federation

${ }^{3}$ Educons University, Faculty of Security Studies, Serbia, bvasic01@gmail.com
} 
Ristić V, et al.: Management of natural wealth - resources curse and socio-economic...

\section{Upravljanje prirodnim bogatstvom - prokletstvo prirodnih resursa i socio-ekonomski razvoj}

Apstrakt: Fenomen resursnog prokletstva je zasnovan na pretpostavci da zemlje koje raspolažu velikim prirodnim resursima nisu u stanju da ostvare adekvatan ekonomski razvoj, i posledično, ne mogu da obezbede dobrobit svojim građanima. Veliki uticaj na ovu pojavu ima neadekvatan način upravljanja ljudskim resursima i visok stepen korupcije. Osnovni cilj ovog rada je preispitivanje osnovnih postavki teorije resursnog prokletstva, utvrđivanje faktora koji su od najjačeg uticaja na njegovo (ne)postojanje, kao i utvrđivanje kauzalne zavisnosti između prirodnog bogatstva i političkog okruženja, kao i kvaliteta života građana. Istraživanje je obavljeno analizom varijabli koje opisuju resursno prokletstvo i Human Development Index. Za obradu podataka korišćen je Fisher's F test. Istraživanje je rađeno na uzorku od 22. Rezultati pokazuju: a) karakteristike političkog režima nemaju jasno definisan uticaj na opstajanje resursnog prokletstva, b) rudna renta i izvoz energenata, nemaju značajan uticaj na kvalitet života građana (izražen preko Human Development Index-a $i$ c) utvrđen je značajan stepen odstupanja od očekivanog u zemljama koje su bogate rudama i metalima.

Ključne reči: prirodno bogatstvo; upravljanje; ekonomski razvoj; socijalna dobrobit

\section{Introduction}

Wealth in natural resources and its management is one of the main challenges of the modern world (Jovanović-Gavrilović and Gligorić, 2018). The "curse of natural resources" phenomenon appears for the first time in scientific literature 1993 (Auty, 1993). even though examples were observed earlier. The first research sought to explain the phenomenon that was evident at that time, and which continued to exist this day, that many countries, rich in natural resources, are unable to provide adequate economic development and well-being for their citizens (from various reasons, some of which will be challenged in this manuscript). In the same time, there are countries with no significant natural wealth and whose development is based exclusively on the import of the necessary resources - are economically more developed, with high level of quality of life. Figure 1 shows that (with exception of Norway, Canada and Australia), all other developed countries are creating GDP with less than $5 \%$ from natural resources since 1970. Average value of GDP derived from natural resources rent is less than 2\% (Van der Ploeg, 2011).

Interaction between economy and politics exists in various forms and with different level of significance (Rakić, Stanojević and Radjenović, 2015). The 
Ristić V, et al.: Management of natural wealth - resources curse and socio-economic...

resource curse, also known as the paradox of plenty, refers to the paradox that countries with an abundance of natural resources (like fossil fuels and certain minerals), tend to have slow economic growth, less democracy, and worse development outcomes than countries with fewer natural resources. When it comes to a somewhat simplified understanding of first postulates, countries with small sizes, initially a high economic level of development and strong state administrative institutions could benefit from the abundance of natural resources. If there is a favourable price situation, the countries with a powerful mining sector are at risk of "getting sick with Dutch disease" (loss of national processing enterprises, competitiveness due to excessive influx of petrodollars into the country), and the political class is losing motivation to pursue an effective economic and political course. Accordingly, large countries with weak institutions of public administration are generally at risk of slipping to collapse (Hodler, 2006).

In general, many studies showed that the main reasons for the existence of a resource curse could be found in the following: resources prices trend and volatility, permanent crowding out of manufacturing and autocratic political regime and oligarchy (Frankel, 2012).

The simple fact that the country is rich in natural resources is not enough, and on that basis it is claimed that its economic growth is threatened. Namely, it is also very important to consider what kind of natural resources is at stake. In the case of countries that are rich in energy resources, breaking the resource curse is possible by improving the work of institutions and strengthening of control mechanisms. On the other hand, the theory of resource curse is still quite acceptable in countries rich in diamonds and precious metals.

\section{Analysis of data}

Natural resources are defined as raw inputs used for manufacturing of all products - extracted or not yet extracted (Coburn, 2012). Even though ranking of countries according to their natural wealth cannot be seen as accurate (mainly because of not sufficient data on resource reserves), it can be accepted ranking done by International Monetary Fund. It classified 51 countries as rich in natural wealth. These are countries "which derive at least $20 \%$ of exports or $20 \%$ of fiscal revenue from non-renewable natural resources. 29 of these countries are low- and lower-middle-income. Common characteristics of these 29 countries include (i) extreme dependence on resource wealth for fiscal revenues, export sales, or both; (ii) low saving rates; (iii) poor growth performance; and (iv) highly volatile resource revenues". 
Ristić V, et al.: Management of natural wealth - resources curse and socio-economic...

Figure 1. Average value of GDP derived from natural resources rent in developed countries (1970 - 2010)

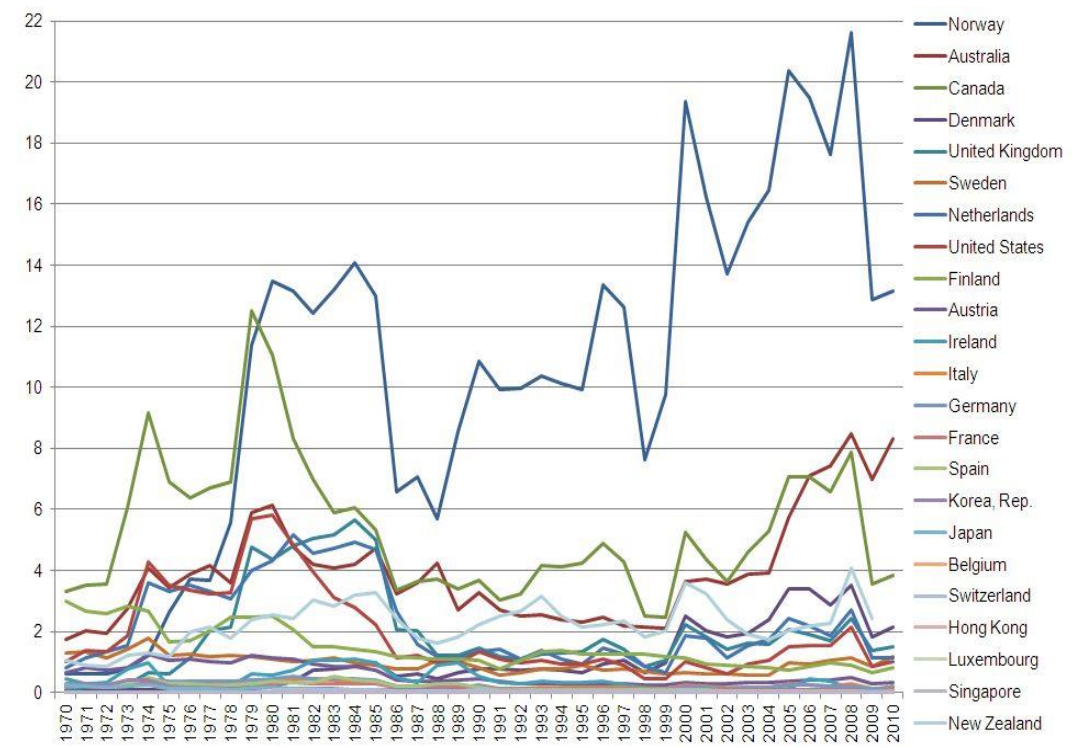

Source: author calculation

On the other hand, contribution of natural resources rent in many underdeveloped countries is at high level, Figure 2.

Figure 2. Natural resources rent in the world (2017). Source: World Bank, Report, 2017.

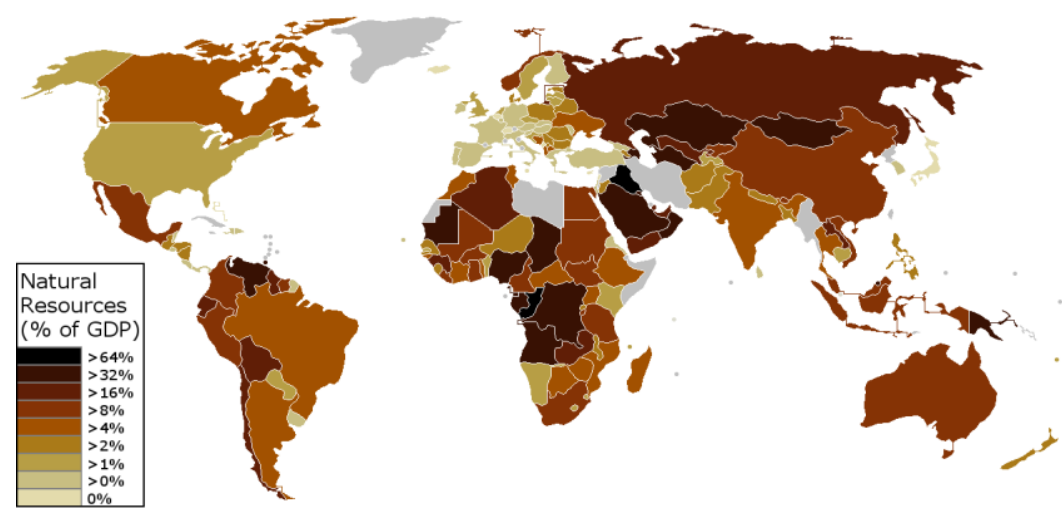

Source: author calculation 
Ristić V, et al.: Management of natural wealth - resources curse and socio-economic...

Revenue from natural resources in countries rich in natural resources vary from $1 \%$ to $91 \%$, Figure 3 .

Figure 3. Revenue from natural resources, selected countries, 2016. Source: International Monetary Fund Report (2016)

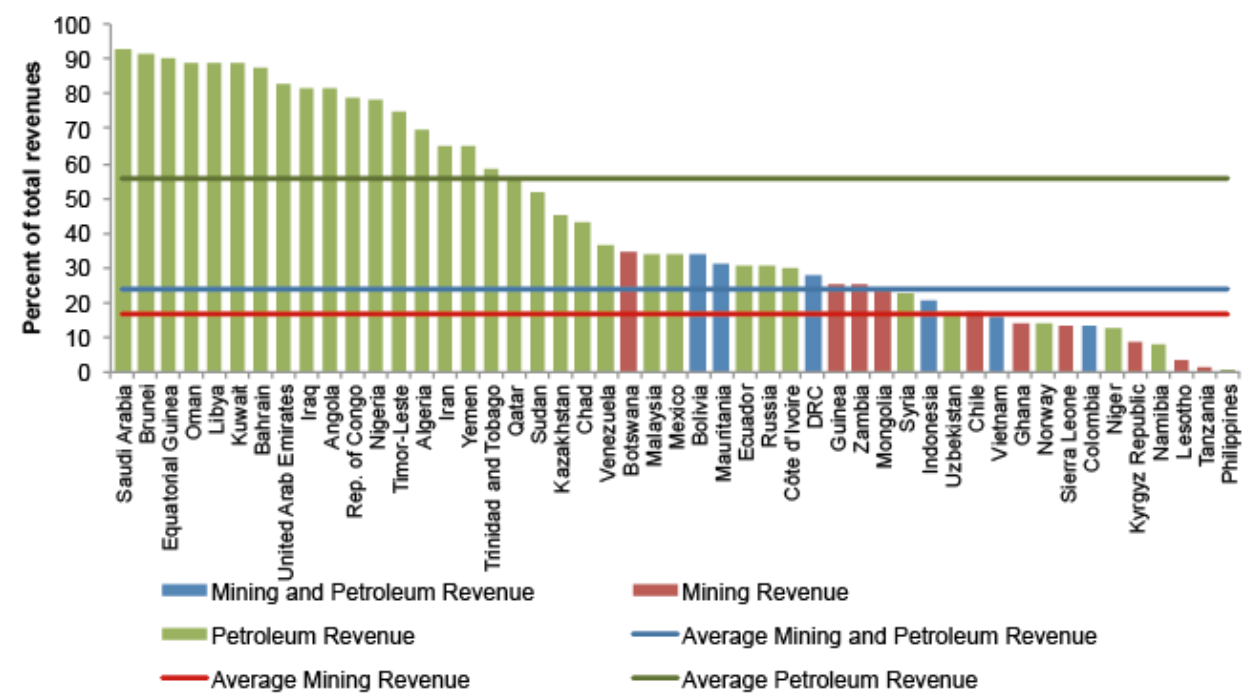

Source: author calculation

There are 10 countries that stands out in natural wealth (Mlachila and Ouedraogo, 2017).

Russian Federation, total estimated natural resources are worth $\$ 75$ trillion, including coal, oil, natural gas, gold and timber. When it comes to rare earth metals, Russian Federation is on second place (after China).

The United States of America, with about $\$ 45$ trillion of wealth in natural resources, $89 \%$ of the country's natural wealth includes coal and timber, plus significant deposits of natural gas, oil, gold and copper.

Saudi Arabia, with $20 \%$ of the world's crude oil reserves and fifth-largest natural gas reserves, worth of $\$ 34.4$ trillion.

Canada, with estimated $\$ 33.2$ trillion worth of commodities; world's secondlargest reserves of uranium and third-largest producer of timber, plus significant reserves of natural gas and phosphate.

Iran, whose main resources are crude oil and natural gas, worth $\$ 27.3$ trillion.

China, with $\$ 23$ trillion of estimated wealth in natural resources, $90 \%$ of which are coal and rare metals. 
Ristić V, et al.: Management of natural wealth - resources curse and socio-economic...

Brazil is estimated to have $\$ 21.8$ trillion in natural wealth: large deposits of gold and uranium and is the world's second-largest producer of iron. Most valuable natural resource of Brazil is timber.

Australia has large reserves of gold, uranium, coal, iron ore and copper. Australia meets $14.3 \%$ of global demand for gold and $46 \%$ of the uranium global supply.

Iraq holds an estimated $\$ 15.9$ trillion worth of natural resources, including oil and phosphate rock.

Venezuela, whose main resources are oil, natural gas and iron, with an estimated \$14.3 trillion worth.

\section{Research methodology}

New tendencies in EU and the world, which include stronger development of industrial sector, which needs natural resources (Cătălin, 2016), and powerful influence of the wealth in natural resources on the political and economic changes in the world today and in the future, (which is frequently subject of unilateral interpretations), imposes the need for analysis of this kind. This research is based on review and interpretation of literature findings and on crossing of opposing opinions on this topic. This study is divided in three parts. In order to chose most appropriate methodology for explanation of resource curse, this research is divided in two parts.

Part one examines causal relationship between natural wealth and five indicators which are pointed in literature as most appropriate for describing impact of natural wealth on country in question. In addition to difficulties in measurement of political concerns, there are also different opinions how to measure natural resources use and its impact on well-being of citizens is given country. Based on literature survey, this study is based on opinion that resource wealth and its impact on economic growth can be measured only by using proxy indicators.

For the purpose of this research, five main elements of resource curse are chosen. These are nature of political regime, Total natural resources rents $(\%$ of GDP), Fuel exports (\% of merchandise exports), Ores and metals exports (\% of merchandise exports) and Human Development Index.

Research covers data for 1990, 1995, 2000, 2005, 2010 and 2015 (as last year which providing available data).

Research sample includes 22 countries, divided in groups (depends on natural wealth): 
Ristić V, et al.: Management of natural wealth - resources curse and socio-economic...

- 10 countries ranked as countries with largest natural wealth;

- 13 countries as largest oil exporters;

- 13 countries as largest ores and metals exporters;

- Norway (as an example of country which successfully avoided resource curse)

Part two is showing time series for each variable and discussion.

Part three covers data processing, For better understanding of causal relationship between variables and their deviations from the average values, Fisher's F-test / Two-tailed test have been applied.

\section{Results and discussion}

\subsection{Natural wealth and political environment}

In early studies, it was declared that richness in natural resources (above all, in crude oil and natural gas) has negative impact on democracy and vice versa. Oil rich countries tend to be and stay in autocratic regime. During decades, studies showed that impact of natural wealth on political regime is ambiguous. In some cases, resource wealth had either positive or negative impact on political regime in certain country (regardless the nature of regime in question), while under certain conditions it can promote the breakdown of democratic regimes for example, among the states of sub-Saharan Africa (Jensen and Wantchekon, 2004).

After 25 years of defining the concept of a "curse of natural resources", it is evident that the prerequisites are not always true. There are countries that are rich in energy resources, have adequate economic growth and ensure a satisfactory quality of life for their citizens. In addition, there are countries rich in energy resources undergoing periods of high political instability (causing external and / or internal factors), which often escalates into certain civil unrest and armed conflicts. Furthermore, certain studies have questioned the basic settings of natural resource curse in general, pointing to examples of commodity-exporting countries that have done well and arguing that resource endowments and booms are not exogenous (Frankel, 2010).

Characteristics of political regime and it causal relationship with natural resources are factors that are often interpreted at only one way. It was set up as an axiom that only capitalistic neoliberal model and democracy can guarantee annulation of natural resources curse. In line with accelerated and increased global geopolitical tensions, besides socio-economic consequences of richness in natural resources, the problems of resource curse became 
Ristić V, et al.: Management of natural wealth - resources curse and socio-economic...

interested in representatives of political science, who drew attention to the political aspects of this phenomenon and led to its reconsideration.

There are also different attitude on causal relationship between energy resources and political regime (in all its aspects), including domestic and foreign policy. In general, it is accepted that negative effects of richness in natural resources are stringer in volatile countries with weak financial and law systems, corruption and presidential democracies (Pegg, 2010).

In addition, it is often suggested that centralized management (characteristic of autocratic regimes) is one of the factors that only strengthen the curse of natural resources, while decentralization could have a positive effect. It turned out that this is not true (Arellano-Yanguas, 2011).

There are several stable models of understanding the relationship of the abundance of energy resources in the country and political processes. In some of these models, scientists are trying to establish a relationship between political institutions and oil and gas resources, in some - between resource abundance and risks of armed conflicts within certain country, which tend to spread the whole region. The logic of the first model has two modifications. The first is based on the view that the abundance of natural resources leads to degradation of political class, the growth of corruption in its ranks and a sharp decline in the effectiveness of institutions, which negatively affects the development of the economy and the state as a whole. The second relies on the notion that the weakness of the institutions is a basic condition that leads to negative consequences of commodity abundance in the country (Robinson, Torvik and Verdier, 2014).

Traditionally, as a way to overcome the curse of natural resources, transparency and accountability from governments often has been suggested. However, there is no empirical evidence that resource-rich countries are less transparent, and whether lack of transparency has a significant negative impact on economic growth. Using "a relatively new index of transparency that has extensive coverage, both across countries and time, the results suggest a strong and robust negative causal association running from (point) resource export revenues to transparency. Furthermore, there is also some evidence that this lack of transparency is associated with a subsequent decrease in economic growth" (Williams, 2011).

On the other hand, the recent studies on Russian Federation indicate that there is no significant impact of the possession of energy resources in the way the state institutions work, the risks of the outbreak of armed conflict and the stability of the political regime. The economic and political strengthening of the Russian Federation after 2000, speaks in favour of fact that initial assumptions of the resource curse and the way of overcoming it must be questioned. It is appropriate in this place to explain the specific circle, defined 
Ristić V, et al.: Management of natural wealth - resources curse and socio-economic...

as one of characteristics of natural resources curse. in the beginning, state institutions are not in a position to control political effects of the "oil golden rain", and, in turn, they would also become its victims, which can be accompanied by a gradual slide of states to authoritarianism and further weakening of institutions. History of changes in Russian Federation proves that energy sources are not necessary curse. It is possible to turn its curse to benefit for all citizens, by introducing adequate energy management (Popova, 2015).

At this point, it is necessary to highlight the different approach and system of values that international companies apply when operating in developed countries and, otherwise, when they operate in countries rich in natural resources with poorly developed system of institutions, protection and control of national interests. Namely, rent-seeking firms (from developing countries, with high level of transparency and rule of law) are rejecting a way of doing business that is acceptable in countries with transparent democracy. Instead, they interact with corrupt governments. The presence or absence of political competition turn out to be key element in generating the resource curse (Bulte and Damania, 2008).

Countries that beat the resource curse are Canada, Chile, Norway and Botswana. All these countries were and still are under different political regimes. Countries where resource curse exists are Nigeria, Angola, Burma, Papua New Guinea, Chad, Pakistan and Sudan. Based on literature review, it can be concluded that nature of political regime has no clear impact on natural wealth management, or existence of resource curse. Therefore, this indicator will be excluded from empirical analysis of this study.

\subsection{Total natural resources rents}

Total natural resources rents are the sum of oil rents, natural gas rents, coal rents (hard and soft), mineral rents, and forest rents. The estimates of natural resources rents are calculated as the difference between the price of a commodity and the average cost of producing it. This kind of taxation contributes to the GDP to a different extent (Kalaš et al, 2017). This is done by estimating the world price of units of specific commodities and subtracting estimates of average unit costs of extraction or harvesting costs (including a normal return on capital). These unit rents are then multiplied by the physical quantities countries extract or harvest to determine the rents for each commodity as a share of gross domestic product (GDP). Performance score from 0 to 100 (World Bank, 2011). Based on the data for named source, authors created a Figure 4. 
Ristić V, et al.: Management of natural wealth - resources curse and socio-economic...

Figure 4. Total natural resources rents (\% of GDP) for selected countries. Source: Authors' calculation based on World Bank data.

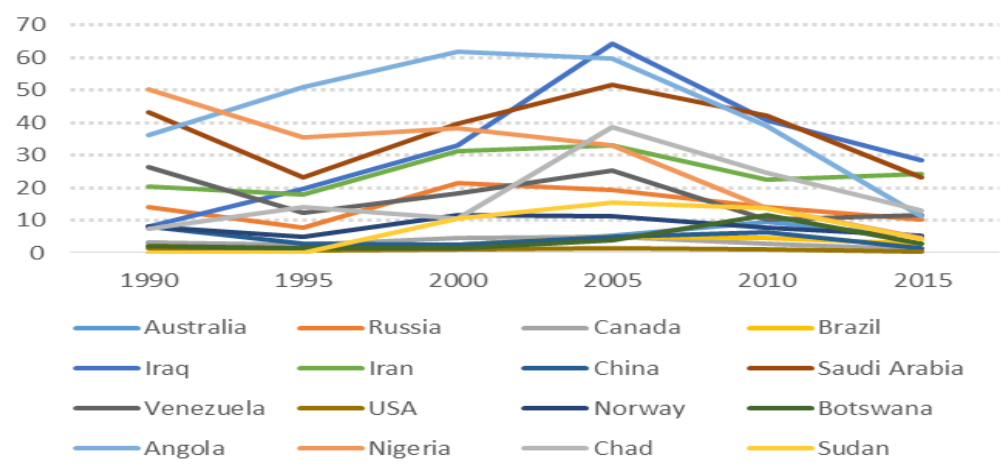

Source: author calculation

\subsection{Fuel exports}

Fuel exports (\% of merchandise exports) is defined as the share of fuel exports in the merchandise exports of the country, expressed in percentage (World Bank staff estimates through the WITS platform from the Comtrade database maintained by the United Nations Statistics Division). Trend of fuel export from selected countries is shown on Figure 5. Chad and Botswana are excluded from this part of study, because these countries has no fuel reserves.

Figure 5. Fuel export (\% of merchandise exports) from selected countries. Source: Authors' calculation based on World Bank data

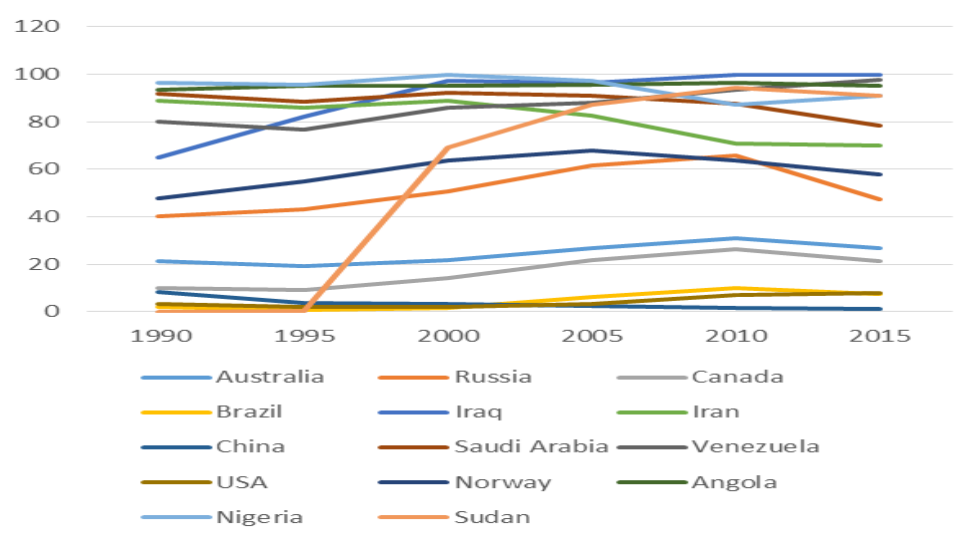

Source: author calculation 
Ristić V, et al.: Management of natural wealth - resources curse and socio-economic...

\subsection{Ores and metals exports}

This part of research excluded Iraq, Iran, Saudi Arabia and Sudan, while included Tanzania, Zimbabwe, Kazakhstan, South Africa and Mongolia - as countries rich in ores and metals. Results are showed on Figure 6.

Figure 6. Ores and metals exports (\% of merchandise exports). Source: Authors' calculation based on World Bank data

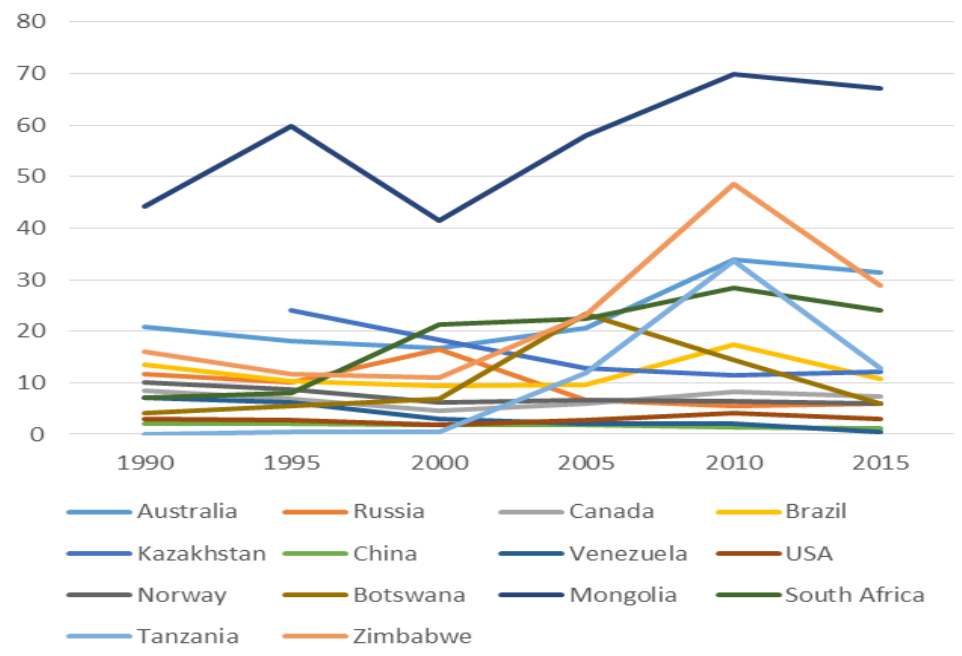

Source: author calculation

\subsection{Human Development Index}

Theory of resource curse is based in the fact that countries, rich in natural resources, has no ability to manage with them properly, and therefore, are not able to provide benefit for their citizens. There are many methodologies on measurement of human wellbeing. Authors decided to use Human Development Index. It was created to emphasize that people and their capabilities should be the ultimate criteria for assessing the development of a country, not economic growth alone. The Human Development Index (HDI) is a summary measure of average achievement in key dimensions of human development: a long and healthy life, being knowledgeable and have a decent standard of living. The HDI is the geometric mean of normalized indices for each of the three dimensions (UNDP, Human Development Reports). Trend of Human Development Index in all 22 selected countries is shown on Figures $7 \mathrm{a}$ and $7 \mathrm{~b}$. 
Ristić V, et al.: Management of natural wealth - resources curse and socio-economic...

Figure 7a. Human Development Index in selected countries. Source: Authors' calculation based on UNDP data

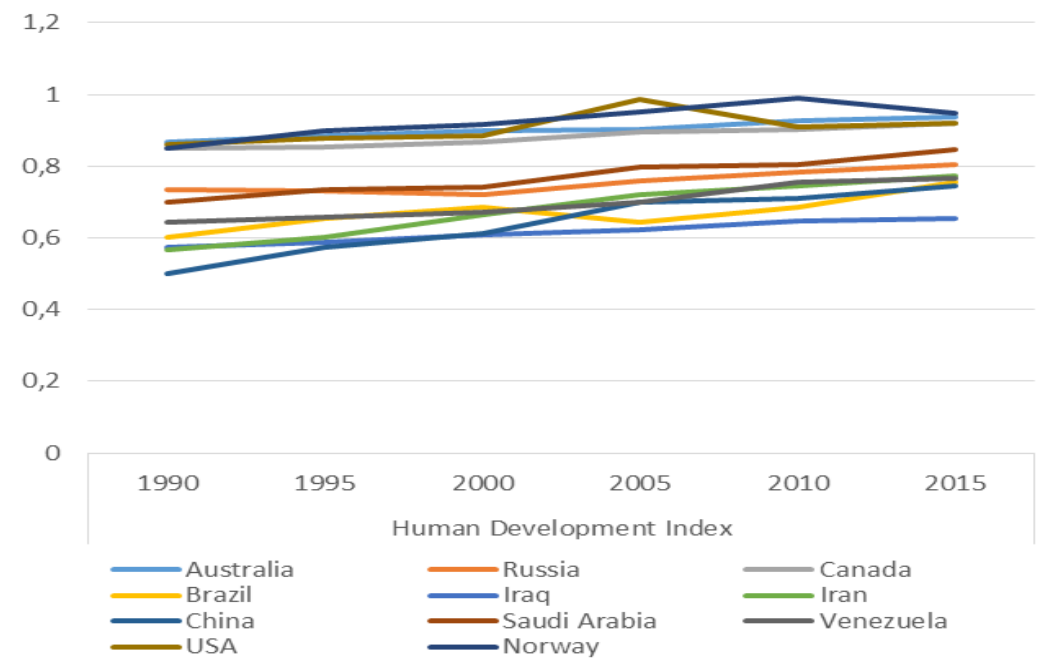

Source: author calculation

Figure 7b. Human Development Index in selected countries. Source: Authors' calculation based on UNDP data

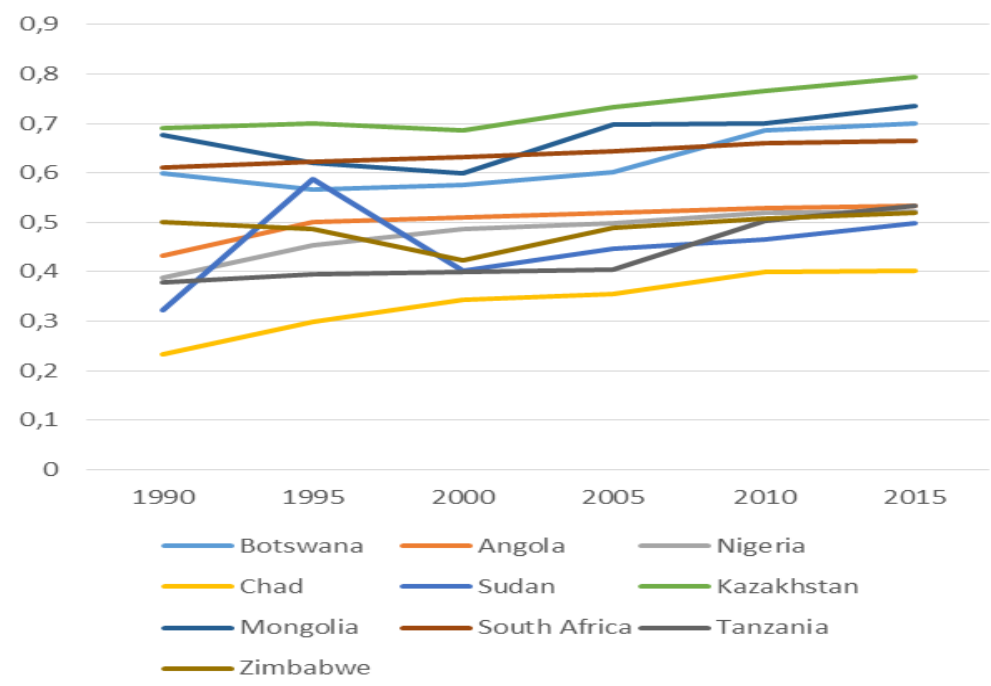

Source: author calculation 
Ristić V, et al.: Management of natural wealth - resources curse and socio-economic...

\subsection{Fisher's F-test}

Fisher's F test, is also known as F-test of equality of variances comparing the respective variances of two samples. This test checks whether the variances of the two samples are equal, assuming that they do not deviate from normality. Fisher's $\mathrm{F}$ test calculates the ratio between the larger variance and the smaller variance. The ratio is then compared to a critical value which depends on the degrees of freedom and on the set value for a (usually 0.05). If the ratio is greater than the critical value, then the null hypothesis $(\mathrm{HO}=$ the variances are equal) is rejected and it can be declared that the variances are different (Ali and Sharma, 1996). In this research null hypothesis is based on assumption that there is significant correlation between chosen variables (Natural resources rent, Energy exports and Ores and metal exports) and Human Development Index.

\subsubsection{Causal relationship between Natural resources rent and HDI}

Statistical overview and results of data processing for 15 selected countries for 1990, 2000 and 2015 are showed at Tables 1, 2 and 3.

Table 1. Fisher's F-test of causal relationship between Natural resources rent and $\mathrm{HDI}$ in selected countries (1990)

\begin{tabular}{|c|c|c|c|c|c|}
\hline Observations & Missing data & Min. & Max. & Mean & Std. dev. \\
\hline 15 & 0 & 0.234 & 0.860 & 0.590 & 0.192 \\
\hline 15 & 0 & 0.010 & 50.350 & 15.450 & 16.343 \\
\hline \multicolumn{2}{|c|}{$\mathrm{F}$ (Critical value) } & \multicolumn{4}{|r|}{2.979} \\
\hline \multicolumn{2}{|l|}{ p-value } & \multicolumn{4}{|r|}{0.434} \\
\hline
\end{tabular}

Source: author calculation

Table 2. Fisher's F-test of causal relationship between Natural resources rent and $\mathrm{HDI}$ in selected countries (2000)

\begin{tabular}{|c|c|l|l|l|r|}
\hline Observations & Missing data & Min. & Max. & Mean & Std. dev. \\
\hline 15 & 0 & 1.100 & 61.960 & 19.253 & 18.082 \\
\hline 15 & 0 & 0.010 & 50.350 & 15.450 & 16.343 \\
\hline$F$ (Critical value) & \multicolumn{5}{|l}{} \\
\hline$p$-value & \multicolumn{5}{|l}{0.710} \\
\hline
\end{tabular}

Source: author calculation 
Ristić V, et al.: Management of natural wealth - resources curse and socio-economic...

Table 3. Fisher's F-test of causal relationship between Natural resources rent and $\mathrm{HDI}$ in selected countries (2015)

\begin{tabular}{|c|c|l|l|l|l|}
\hline Observations & Missing data & Min. & Max. & Mean & Std. dev. \\
\hline 15 & 0 & 0.402 & 0.949 & 0.719 & 0.167 \\
\hline 15 & 0 & 0.290 & 28.640 & 9.671 & 9.190 \\
\hline F (Critical value) & & & & 2.979 \\
\hline p-value & \multicolumn{5}{|l}{} \\
\end{tabular}

Source: author calculation

\subsubsection{Causal relationship between Energy exports and HDI.}

Statistical overview and results of data processing for 13 selected countries for 1990, 2000 and 2015 are showed at Tables 4, 5 and 6.

Table 4. Fisher's F-test of causal relationship between Energy exports and $H D I$ in selected countries (1990)

\begin{tabular}{|c|c|l|l|l|l|}
\hline Observations & Missing data & Min. & Max. & Mean & Std. dev. \\
\hline 15 & 0 & 0.322 & 0.860 & 0.617 & 0.178 \\
\hline 15 & 0 & 0.010 & 96.630 & 48.285 & 39.612 \\
\hline $\mathrm{F}$ (Critical value) & \multicolumn{5}{|r}{} \\
\hline p-value & \multicolumn{5}{|l}{0.101} \\
\hline
\end{tabular}

Source: author calculation

Table 5. Fisher's F-test of causal relationship between Energy exports and $H D I$ in selected countries (2000)

\begin{tabular}{|c|c|l|l|l|r|}
\hline Observations & Missing data & Min. & Max. & Mean & Std. dev. \\
\hline 15 & 0 & 1.100 & 61.960 & 19.253 & 18.082 \\
\hline 15 & 0 & 0.010 & 50.350 & 15.450 & 16.343 \\
\hline $\mathrm{F}$ (Critical value) & \multicolumn{5}{|l}{} \\
\hline p-value & \multicolumn{5}{|l}{0.710} \\
\hline
\end{tabular}

Source: author calculation 
Ristić V, et al.: Management of natural wealth - resources curse and socio-economic...

Table 6. Fisher's F-test of causal relationship between Energy exports and $H D I$ in selected countries (2015)

\begin{tabular}{|c|c|c|c|c|c|}
\hline Observations & Missing data & Min. & Max. & Mean & Std. dev. \\
\hline 13 & 0 & 0.498 & 0.949 & 0.745 & 0.153 \\
\hline 13 & 0 & 0.010 & 96.630 & 48.285 & 39.612 \\
\hline $\mathrm{F}$ (Critical value) & \multicolumn{4}{|l}{3.277} \\
\hline$p$-value & \multicolumn{5}{|l}{0.334} \\
\hline
\end{tabular}

Source: author calculation

\subsubsection{Causal relationship between Ores and metals export and HDI}

Statistical overview and results of data processing for 12 selected countries for 1990, 2000 and 2015 are showed at Tables 7, 8 and 9.

Table 7. Fisher's F-test of causal relationship between Ores and metals export and HDI in selected countries (1990)

\begin{tabular}{|c|c|c|c|c|c|}
\hline Observations & Missing data & Min. & Max. & Mean & Std. dev. \\
\hline 12 & 0 & 0.378 & 0.860 & 0.658 & 0.152 \\
\hline 12 & 0 & 0.110 & 44.200 & 11.394 & 11.422 \\
\hline \multicolumn{2}{|c|}{$\mathrm{F}$ (Critical value) } & \multicolumn{4}{|r|}{3.277} \\
\hline \multicolumn{2}{|l|}{$p$-value } & \multicolumn{4}{|r|}{0.101} \\
\hline
\end{tabular}

Source: author calculation

Table 8. Fisher's F-test of causal relationship between Ores and metals export and HDI in selected countries (2000)

\begin{tabular}{|c|c|c|c|c|c|}
\hline Observations & Missing data & Min. & Max. & Mean & Std. dev. \\
\hline 15 & 0 & 0.399 & 0.917 & 0.675 & 0.163 \\
\hline 15 & 0 & 0.540 & 41.410 & 11.330 & 11.754 \\
\hline \multicolumn{2}{|c|}{ F (Critical value) } & \multicolumn{4}{|r|}{3.474} \\
\hline \multicolumn{2}{|l|}{ p-value } & \multicolumn{4}{|r|}{0.007} \\
\hline
\end{tabular}

Source: author calculation 
Ristić V, et al.: Management of natural wealth - resources curse and socio-economic...

Table 9. Fisher's F-test of causal relationship between Ores and metals export and HDI in selected countries (2015)

\begin{tabular}{|c|c|c|c|c|c|}
\hline Observations & Missing data & Min. & Max. & Mean & Std. dev. \\
\hline 13 & 0 & 0.440 & 67.250 & 14.993 & 18.595 \\
\hline 13 & 0 & 0.520 & 0.949 & 0.759 & 0.138 \\
\hline \multicolumn{2}{|c|}{ F (Critical value) } & \multicolumn{4}{|r|}{3.474} \\
\hline \multicolumn{2}{|l|}{ p-value } & \multicolumn{4}{|r|}{0.003} \\
\hline
\end{tabular}

Source: author calculation

Main findings are showing that biggest gap between expected socio-economic wellbeing of citizens in countries rich in natural resources exists in case of countries rich in diamonds and precious metals, mostly in Sub-Saharan Africa. As main reason for this, researchers indicate poor governmental institutions and corruption. This result of this study is in line with finding of several studies on this rather controversial topic.

Theoretical settings and research in the field of natural resources say that one of the crucial factors that influence the overflow of the curse of natural resources is adequate human resources management. It should be kept in mind that the exploitation of natural resources is extremely complex and encompasses a large number of participants from different sectors: central government, policy makers, financial services (national and international). It involves persons (and groups) with different types of indebtedness and levels of responsibility. In addition, the issue of natural regrowth is a complex geopolitical issue.

Corruption in resource-rich countries takes two main forms, rent seeking and patronage. Resource rents induce rent seeking as individuals compete for a share of the rents rather than use their time and skills more productively. In addition, resource revenues induce patronage as governments pay off supporters to stay in power, resulting in reduced accountability and an inferior allocation of public funds (Kolstad and Søreide, 2009).

Systemic strengthening of state institutions in countries rich in natural wealth, adequate human resource management and the fight against corruption are a prerequisite for eradication of poverty in certain countries rich in natural resources. The above can be accomplished by developing effective and appropriate human resources management principles and practices, under the following heading (Pawan and Yaw, 2013);

- Accommodating the interests of multiple stakeholders by developing effective decision-making processes that give voice to these interests; 
Ristić V, et al.: Management of natural wealth - resources curse and socio-economic...

- Obtaining commitment and motivation by reconciling conflicts between work and home/community living;

- Assessing the appropriateness of management techniques in different socio-cultural context.

In order to effectively fight corruption, it is necessary to use established strategies (Tahseen and Eatzaz, 2010): paying civil servants well, creating transparency in government spending, replacing regressive and distorting subsidies with targeted cash transfers, establishing international conventions and deploying smart technologies.

\section{Conclusions}

Wealth in natural resources is one of the most important advantages any economy can have as today, as well in the future. During history, natural resources were extracted with minimum or no attention on environment and social wellbeing. The problem of the possession of natural resources has become even more important in the 21st century, when global geopolitical tensions are growing while the need for resources is getting bigger. The situation is further complicated with the fact that natural wealth is concentrated in ten countries of the world, in which there are different political regimes, and the management of resources is organized in different ways (with less, greater or complete control) by the governmental institutions.

The phenomenon of the resource curse assumes that countries that possess a vast natural wealth, but do not developed a high degree of democracy (countries in which authoritarian regimes are governed), are unable to exploit their own natural resources for the benefit of their citizens.

The main objective of this paper was to examine the impact of the basic variables that describe the richness in natural resources and their impact on the quality of life of citizens. First, the results of the research have shown that the type of political regime in a given country has no impact on the management of natural wealth for the benefit (or damage) of citizens. Secondly, the research included the assessment of three basic proxy indicators that quantitatively describe resource wealth: Natural resources rent, Energy export and Ores and metal exports. Human Development Index was chosen as a measure of social welfare of citizens. The research showed that Natural Resources rent and Energy export have no impact on the Human Development Index. In the same time, Human Development Index level is rising, but not proportionally to the changes in these indicators.

The only indicator that supports the theory of the resource curse is found in Sub-Saharan Africa, countries with large reserves of diamonds and precious 
Ristić V, et al.: Management of natural wealth - resources curse and socio-economic...

metals. At the time of colonialism, resources were exploited from these countries without any compensation for the country of origin or its citizens. In these countries problem of adequate management of natural resources has been maintained to date. The research has shown that the level of Human Development Index in these countries is far below what is expected.

As one of the largest and most resistant barriers that exist to fight the curse of natural resources, especially in the countries of sub-Saharan Africa, is inadequate management of human resources and high level of corruption. Management science knows the basic strategies that can be used in this direction, but above all, it is necessary commitment of the national government and all institutions to organize oppose against this extremely harmful social phenomenon.

Future of natural wealth management is of great importance. Natural resources belong to the people. Profits should benefit the people, not a company or the individual who own the ground where natural gas or iron ore was found. A strong and universal principle of natural resource ownership by the people will increase pressure on governments to use revenues for public services rather than for private gain.

Future of natural resources (and curse of natural resources) is significantly changed by emerging of post-neoliberal resource nationalist regimes seeking socially inclusive national development strategies, including one with populist and resource nationalist orientation.

Results of this research, and literature survey proves that socio-economic and political well-being of natural wealth rich countries depends on the actors involved. In addition, there is universal attitude that resource curse should be removed. However, the literature does not provide clear proposal of management and political changes needed to overcome this phenomenon. Having in mind main findings of this paper, it is clear that major focus should be on natural wealth management itself. This manuscript is suggesting that natural resources must be viewed as strategic resources and must be managed as such. In particular, this refers to the introduction of a centralized integrated management system, with strictly defined hierarchy, security and business intelligence.

\section{References}

Ali, M.M., \& Sharma, S.C. (1996). Robustness to nonnormality of regression Ftests. Journal of Econometrics,71(1-2), 175-205. doi:10.1016/03044076(94)01700-x 
Ristić V, et al.: Management of natural wealth - resources curse and socio-economic...

Arellano-Yanguas, J. (2011). Aggravating the Resource Curse: Decentralisation, Mining and Conflict in Peru. Journal of Development Studies, 47(4), 617-638. doi:10.1080/00220381003706478

Auty, R. (1993). Sustaining Development and Mineral Economies: The Resource Curse Thesis. New York: Oxford University Press.

Bulte, E., \& Damania, R. (2008). Resources for Sale: Corruption, Democracy and the Natural Resource Curse. The B.E. Journal of Economic Analysis \& Policy, 8(1), doi:10.2202/1935-1682.1890

Cătălin, V. (2016). Changes of EU industrial policy and its effects on Romania's industrial paradigm. Industrija, 44(4), 197-210. doi:10.5937/industrija44-12011

Coburn, T.C. (2000). Geostatistics for Natural Resources Evaluation. Technometrics, 42(4), doi:10.1080/00401706.2000.10485733

Frankel, J. (2012). The Natural Resource Curse: A Survey of Diagnoses and Some Prescriptions. HKS Faculty Research Working Paper, Series RWP12-014, John F. Kennedy School of Government, Harvard University..

Frankel, J. (2010). The Natural Resource Curse: A Survey. Cambridge, MA: National Bureau of Economic Research. doi:10.3386/w15836

Hodler, R. (2006). The curse of natural resources in fractionalized countries. European Economic Review, 50(6), 1367-1386. doi:10.1016/j.euroecorev.2005.05.004

Jensen, N., \& Wantchekon, L. (2004). Resource Wealth and Political Regimes in $\begin{array}{lll}\text { Africa. Comparative Political } & \text { 8tudies, 37(7), }\end{array}$ doi:10.1177/0010414004266867

Jovanović-Gavrilović, B., \& Gligorić, M. (2018). Fundamentalni pokretači prosperiteta u zemljama Evropske unije i Zapadnog Balkana. Industrija, 46(1), 155-171. doi:10.5937/industrija46-16696

Kalaš, B., Milenković, I., Pjanić, M., Andrašić, J., \& Milenković, N. (2017). The impact of tax forms on economic growth: Evidence from Serbia. Industrija, 45(2), 113125. doi:10.5937/industrija45-12978

Kolstad, I., Søreide, T. (2009). Corruption in natural resource management: Implications for policy makers, Resources Policy, 34(4): 214-226.

Mlachila, M., \& Ouedraogo, R. (2017). Financial Resource Curse in Resource-Rich Countries. IMF Working Papers, 17(163), 1. doi:10.5089/9781484310144.001

Pawan, S. B., Yaw, A. D. (2013) Human resources management in developing countries, Routledge.

Pegg, S. (2010). Is there a Dutch disease in Botswana?. Resources Policy, 35(1), 1419. doi:10.1016/j.resourpol.2009.07.003

Popova, O.V. (2015). Political aspects of the resources curse. In Proceedings of Saint Petersburg State University, Russian Federation. 26-38; 2.

Rakić, B., Stanojević, J., \& Rađenović, T. (2015). Political cycles' influence on inflation and unemployment. Industrija, 43(2), 89-104. doi:10.5937/industrija43-7922

Robinson, J.A., Torvik, R., \& Verdier, T. (2014). Political foundations of the resource curse: A simplification and a comment. Journal of Development Economics, 106, 194-198. doi:10.1016/j.jdeveco.2013.09.004

Tahseen, A., Eatzaz, A. (2010). The Effect of Corruption and Governance on Tax Revenues, The Pakistan Development Review, 49(4): 405-417.

-UNDP. Human Development Reports.

Ploeg, F.v. (2011). Natural Resources: Curse or Blessing. Journal of Economic Literature, 49(2), 366-420. doi:10.1257/jel.49.2.366 
Ristić V, et al.: Management of natural wealth - resources curse and socio-economic...

Williams, A. (2011). Shining a Light on the Resource Curse: An Empirical Analysis of the Relationship Between Natural Resources, Transparency, and Economic Growth. World Development, 39(4), 490-505. doi:10.1016/j.worlddev.2010.08.015

-World Bank. (2011). The Changing Wealth of Nations: Measuring Sustainable Development in the New Millennium.

-World Bank. (2017). Report.

-International Monetary Fund. (2016). Report. 